\title{
Public perception of human trafficking: a case study of Moldova
}

Ludmila Bogdan (D)

\author{
Correspondence: Ludmila.bogdan@ \\ snc.edu \\ Moldova State University \\ (Universitatea de Stat din Moldova), \\ Alexei Mateevici Street 60, Chișinău, \\ Republic of Moldova
}

\begin{abstract}
For two decades, counter-trafficking organizations have been operating under the assumption that rural populations are less informed about human trafficking. Based on a public survey of 300 people in Moldova, I found that anti-trafficking organizations operating in Moldova have flawed assumptions about the public knowledge. Findings show that rural people are, in fact, more knowledgeable about human trafficking than other surveyed groups. In-depth interviews revealed that these people are more informed than others because (1) anti-trafficking organizations mainly have targeted them, (2) they are more likely to know families who have lost members to the traffickers, (3) they tend to think of themselves more likely to be trafficked because they share the same characteristics with the trafficked victims. These findings suggest that counter-trafficking organizations have to revise their anti-trafficking efforts and re-conceptualize the targeted population for their work to be more efficient in tackling this problem.
\end{abstract}

Keywords: Human trafficking, Counter-trafficking policies, Public awareness, Moldova

\section{Introduction}

The United Nations agencies argue that the most significant challenges in tackling human trafficking are targeting criminals, protecting victims, and educating the public about trafficking risks (UNFPA 2011; UNODC 2014; UNODC 2008). Worldwide, international organizations and national governments have enhanced their efforts to combat factors and drivers of human trafficking by raising public awareness on this issue to women and rural people in particular (IOM 2013; OSCE 2018). The International Organization for Migration (IOM), in cooperation with local governments, United Nations agencies, the European Commission, the Organization for Security and Co-operation in Europe (OSCE), and non-governmental organizations (NGOs) have conceptualized, produced, and implemented anti-trafficking measures in Europe. After that, I will use only 'anti-trafficking organizations,' 'counter-trafficking organizations,' or 'organizations' to avoid repeating the list of the entities mentioned above involved in counter-trafficking work in Europe.

Anti-trafficking organizations operate under the assumption that poorly educated, rural residents and people from economically deprived backgrounds lack both

(c) The Author(s). 2020 Open Access This article is licensed under a Creative Commons Attribution 4.0 International License, which permits use, sharing, adaptation, distribution and reproduction in any medium or format, as long as you give appropriate credit to the original author(s) and the source, provide a link to the Creative Commons licence, and indicate if changes were made. The images or other third party material in this article are included in the article's Creative Commons licence, unless indicated otherwise in a credit line to the material. If material is not included in the article's Creative Commons licence and your intended use is not permitted by statutory regulation or exceeds the permitted use, you will need to obtain permission directly from the copyright holder. To view a copy of this licence, visit http://creativecommons.org/licenses/by/4.0/. 
resources and capabilities necessary to educate themselves about human trafficking (Arap 2017; COE 2012; GRETA 2016; Ghimpu et al. 2011; IOM 2013; OSCE 2018; Radeva 2013; Rusu 2013; UN 2015; UNFPA 2011). Since 2000, IOM has sustained that "the population that lives below or near the poverty line, [with] low level of education, as well as [fewer] job prospects within the country or the local communities" (IOM 2018, p. 3) continue to be vulnerable to trafficking.

In this paper, I test if these organizational assumptions about public knowledge coincide with the actual public knowledge on this problem. First, I had consulted secondary published reports from 2000 until 2014 to investigate organizational assumptions about public knowledge. Then, I conducted a public survey and measured how informed the public is about different aspects of this problem. Later, I compared if the organizational assumptions coincide with the reality reflected in my survey. This observation is essential because this is one indicator of whether organizations base their anti-trafficking prevention policies on accurate and updated information.

The paper is structured in the following way: the first section provides general information about human trafficking. The second section presents background information on Moldova and the main reasons why it is used as a case study. The following part lays out the main arguments of this paper and the hypotheses that are tested. Section four details the data and methodology used to test the proposed hypotheses. In section five, I discuss the main results. Findings show that rural people are more knowledgeable about human trafficking because (1) anti-trafficking organizations mainly have targeted them, (2) they are more likely to know families who have lost members to the traffickers, (3) they tend to think that people are more likely to be trafficked, and (4) they share the same characteristics with the trafficked victims. The last two sections elaborate on broader explanations of the main findings and provide recommendations to policymakers.

\section{A case study of Moldova}

Moldova is a small country between Romania and Ukraine that gained its independence from the Soviet Union in 1991. Shortly after, the transition from a communist system to a free market-economy caused an economic crisis, which consequently led to high rates of poverty and unemployment. The country went from one of the most flourishing countries in the Soviet Union to the poorest country in Europe (World Bank 2019). After 1991, the slow development in the agricultural sector worsened the quality and access to health and education in rural areas. Since the Moldovan economy depended on agricultural exports to the Soviet republics, the dissolution of the union brought down the food prices in the weak economy (Clark and McArthur 2014). The negative impact in the agricultural sector affected almost half of the Moldovan population that was employed in that sector.

Poverty in Moldova has been characterized by low wages, unemployment, and limited political participation among citizens. While poverty has affected the entire population of Moldova, it affected more severely vulnerable populations such as those residing in rural areas, those without jobs, and educational training (Nanu 2010). Several faulty economic, political, and social factors - such as economic deterioration, increased violence, discrimination, and political instability - led Moldova to become a significant source for trafficking in human beings (UNDP 2006). Transnistrian conflict only fuels 
the problem of human trafficking. In 1990, the "Pridnestrovian Moldavian Soviet Socialist Republic" (Transnistria) self-proclaimed independent from Moldova with its capital located in Tiraspol. In 1992, the political tensions escalated into a civil war and eventually evolved into a frozen conflict. The conflict remains unresolved until this day.

Although in the 1990s, Eastern Europe has surfaced as a substantial source of victims of human trafficking (Kartusch 2001), Moldova has been considered to have the highest rates of trafficking victims (IOM 2019). A study compared the most severely affected countries by this problem in Eastern Europe, including Belarus, Bulgaria, Moldova, Romania, and Ukraine, and found that Moldova has had by far the highest prevalence of human trafficking among the studied countries (Mahmoud and Trebesch 2010).

Counter-trafficking organizations operating in Moldova have been actively engaged in drafting and implementing prevention campaigns targeting women, poorer, and rural people in Moldova (Arap 2017; Botchkovar et al. 2016; COE 2012; GRETA 2016; GRETA 2012; IOM 2013; Motriuc 2012; Radeva 2013; UN 2015). They have been raising awareness about this problem to the general public by conducting educational programs for youth, training a wide range of professionals such as social assistants, police, and local administrative officials, and holding national and international conferences (Arap 2017; COE 2012; GRETA 2016; IOM 2018; LaStrada 2017; OSCE-Moldova 2016; Rusu 2013).

Moldovan case study is essential due to several reasons. First, Moldova is a country with some of the highest rates of outmigration, poverty, and human trafficking in the region (World Bank, 2018). Second, Moldova has attracted a lot of anti-trafficking funding and efforts (UNODC 2014; UN-Moldova 2007; UNFPA 2011). Third, Moldova is an understudied area when it comes to academic research on migration and human trafficking (Robinson 2011; Rusu 2013; Surtees 2005).

\section{Hypotheses}

I have looked at the anti-trafficking organizations' assumptions, operating in Moldova, regarding what groups of people are less informed about human trafficking and what my data shows regarding the knowledge levels of human trafficking. Revised literature showed that anti-trafficking organizations act on the assumption that "rural people," "poorer people," "lower social class people," and "less educated people" are less informed about human trafficking because these people are more likely to be trafficked. Based on these assumptions, I propose to test the following:

\section{H1: The level of education does not influence the knowledge levels of human trafficking.}

Anti-trafficking experts claim that the level of education is directly correlated with the knowledge level of human trafficking - more education translates into more knowledge about human trafficking. However, I hypothesize that education levels do not have a significant impact on public knowledge of human trafficking. Human trafficking is a social problem, which can be understood by all citizens regardless of their educational background.

H2: Social class negatively correlates with knowledge levels of human trafficking.

Anti-trafficking organizations have been targeting, through its awareness campaigns, more frequently people from lower social classes. Thus, I hypothesize that social class 
will negatively correlate with knowledge about trafficking, which means that people from lower social classes will be more informed about human trafficking, and people from higher social classes will be less informed about different aspects of this problem.

\section{H3: Salary negatively correlates with knowledge levels of human trafficking.}

Human trafficking policymakers explain that the more impoverished people have less knowledge about human trafficking as a result of their lower education, fewer economic resources, and less access to information compared to those who are from more prosperous economic backgrounds. Human trafficking, as many other problems have been framed as "the problem of the poor." This framing convinces these people that this is a problem they need to be informed about. Thus, I hypothesize that people with lower wages, which indicates an unfavorable economic background, would be more informed about this problem.

\section{H4: Rural residents are more knowledgeable about human trafficking, while urban residents are less knowledgeable about human trafficking.}

Anti-trafficking organizations operating in Moldova have been targeting through prevention programs and information campaigns, mainly people from the rural area, because they believe these people are less informed about this phenomenon. The rural area has been targeted because residents are more impoverished, with lower education rates, fewer economic resources, and less access to information compared to those who reside in urban areas. I explain that precisely because of these targeting strategies, people from the rural area would be more informed about different aspects of this problem.

\section{Data and methods}

For this study, I used a mixed-method approach. First, I analyzed the policy reports published on people's vulnerability to human trafficking, provided by anti-trafficking organizations (such as UN agencies, IOM, OSCE, and local NGO chapter LaStrada) between 2000 and 2014. Then, I conducted a public survey to measure the general knowledge about this problem. Finally, I compared the public knowledge about this crime with organizational perception about public knowledge.

The data analyzed here have been generated by a face-to-face public survey based on a questionnaire to study public perception about social problems in Moldova, including knowledge about human trafficking. The survey concentrated on the Moldovan general public, investigating the main aspects of human trafficking - knowledge, experience, and expectations regarding the problem of human trafficking. The data were collected through face-to-face interviews of a national sample of people (aged 14 and older) living in Moldova between May 2013 and September 2014 based on one questionnaire to gather information on public perception about social problems in Moldova. I collected the interviews based on randomization, considering the group of regions and households. Three randomization stages were applied: locality - selected randomly for each stratum using a table of random numbers; house - in each district, based on street routes, which were designed depending on the number of interviews per locality. 
The random selection of locality was followed by choosing the household from the center of the locality following a route. The route captured people from the center of the residential area to its periphery. Most households directed me to talk to younger members of the family, which perhaps biased my study towards more youthful people. Respondents were told that they would be asked personal-opinion type questions emphasizing that there were no wrong or right answers, but that the researcher was interested in their views on some social issues. The questionnaire was translated into the two mainly spoken languages in Moldova, Romanian, and Russian. I speak both languages fluently. Then the questionnaire was pre-tested by asking ten people during the pilot research. This approach helped identify questions that could be misunderstood or misinterpreted by respondents. Subsequently, the questionnaire was improved and adapted to the target.

The survey consisted of approximately fifty questions aimed at obtaining information about critical issues such as level of education, occupation, earnings, family status, prior migration and mobility experience, knowledge, and perception about human trafficking in Moldova. In general, questions related to human trafficking were mixed with other questions regarding the general opinion about the situation in Moldova, including demographic information. All questions were open-ended to allow respondents to express their views, opinions, and experience without biasing their responses with a predetermined list of answers.

In this article, I focus specifically on the awareness and knowledge about human trafficking among Moldovans. An average respondent of this survey is a middle-class citizen, between 14 and 25 years old, with a finished high school degree, residing in rural areas in the central part of Moldova, and earning less than 300 USD/month (see Table 1). My survey has 300 valid responses from people residing in Moldova. Women constitute 54\% of the sample, and men $-46 \%$.

This article combines a descriptive statistical analysis of the main features of respondents with a qualitative discourse analysis of their in-depth answers to the open-ended questions. The in-depth answers to questions related to migration motivations were analyzed following the method of qualitative discourse analysis. I looked at the discursive strategies that respondents used to explain their perception of this problem and its consequences on the society and them personally. The analysis of these discursive strategies helps to understand how their discourse over knowledge and awareness about human trafficking matters related to their social life and experiences.

The public knowledge about human trafficking is measured based on how accurate the given definition was. There have been several indicators to measure the accuracy of human trafficking definition - age and gender of people who can be trafficked, how often people hear about this problem, and how many types of trafficking people could enumerate.

\section{Dependent variables}

\section{Trafficking definition (gender)}

Respondents were asked people of what gender can be trafficked? Their responses ranged from "females," "males," "any gender." About 33\% of respondents said that only 'females' could be trafficked; the rest, $67 \%$ said that people of any gender could be trafficked. 
Table 1 The number of interviews conducted in Moldovan regions

\begin{tabular}{llllll}
\hline Region & Interviews & FIPS & Code & Population & Capital \\
\hline Anenii Noi & 8 & MD59 & 10 & 81,719 & Anenii Noi \\
Bălţi & 12 & MD60 & 03 & 127,673 & Bălți \\
Basarabeasca & 3 & MD61 & 12 & 28,978 & Basarabeasca \\
Briceni & 7 & MD63 & 14 & 77,978 & Briceni \\
Cahul & 9 & MD64 & 17 & 119,201 & Cahul \\
Călăraşi & 7 & MD66 & 25 & 75,167 & Călăraşi \\
Cantemir & 5 & MD65 & 21 & 60,008 & Cantemir \\
Căuşeni & 8 & MD67 & 27 & 90,616 & Căuşeni \\
Chişinău & 60 & MD57 & 01 & 716,530 & Chişinău \\
Cimişlia & 6 & MD68 & 29 & 60,936 & Cimişlia \\
Criuleni & 7 & MD69 & 31 & 72,259 & Criuleni \\
Donduşeni & 4 & MD70 & 34 & 46,437 & Donduşeni \\
Drochia & 8 & MD71 & 36 & 87,083 & Drochia \\
Dubăsari & 3 & MD72 & 38 & 34,004 & Cocieri \\
Edineţ & 8 & MD73 & 41 & 81,384 & Edineţ \\
Făleşti & 7 & MD74 & 43 & 89,915 & Faleşti \\
Floreşti & 8 & MD75 & 45 & 89,406 & Floreşti \\
Găgăuzia & 12 & MD51 & 96 & 155,781 & Comrat \\
Glodeni & 6 & MD76 & 48 & 60,968 & Glodeni \\
Hînceşti & 10 & 53 & 119,765 & Hînceşti \\
laloveni & 9 & 55 & 97,759 & laloveni \\
Leova & 5 & 60 & 51,161 & Leova \\
Nisporeni & 6 & 62 & 64,945 & Orher \\
Ocnița & 5 & 64 & 116,296 & \\
Orhei & 10 & & & \\
\hline & & MD82 & & \\
\hline
\end{tabular}

Trafficking definition (age)

Respondents were asked people of what age can be trafficked? Their responses ranged from "young," "mature," "any age." The majority of respondents, 54\%, said that people of any age could be trafficked, followed by those $(23 \%)$ who think that only young people can be trafficked, and those (22\%) who think that only mature people can be trafficked.

\section{Trafficking information exposure}

Respondents were asked people how often they hear about this problem without actively seeking information on this topic. Their responses ranged from "Weekly," "monthly," "yearly." The opinion poll shows that $40 \%$ of respondents have heard of human trafficking during the week they have been surveyed, followed by $31 \%$ of those who have heard of it in the same month they have been surveyed, and 29\% have not heard about this crime in years.

\section{Trafficking types}

Respondents were asked to identify and enumerate all types of human trafficking they knew. Most people (42\%) identified three types of human trafficking, followed by those 
(35\%) who identified two types of human trafficking. The third group (10\%) identified four types, and $2 \%$ identified five types. Another $10 \%$ identified only one type of human trafficking (sex trafficking). The rest, 1\% could not identify any type of human trafficking.

\section{Independent variables}

Residency

Respondents in the sample are categorized into three distinct categories: rural, urban, and capital city residents. Most of the respondents reside in rural areas in 54\% and 46\% in the urban area, from which $20 \%$ reside in the capital city, Chisinau.

\section{Education}

Respondents were asked how many years of education they had completed (numerical variable). However, for the regressions, a new categorical variable with four categories was created: Middle School - those who have had nine or fewer years of education; High School - those who have had between 12 and 10 years of education; Undergraduate education - those who have had between 13 and 15 years of education; Postgraduate education - those who have had more than 15 years of education. About $45 \%$ of polled people had a high school education, $36 \%$ have had an undergraduate education, $17 \%$ have a middle school education, and $2 \%$ have a postgraduate education.

\section{Social class}

Respondents were asked to what social class they belonged to. Therefore, their responses might have been biased, but there was no better way to find out what their social class was than asking them about it. According to their responses, the overwhelming majority (64\%) identified as middle-class citizens, followed by lower social class citizens (27\%) and higher social class people (9\%).

\section{Wages}

Respondents were asked about their monthly salaries. They had the option to choose between three categories: low salary when monthly wages were less than 3000 Lei; average salary when between 3000 and 6000 Lei, and high salary when more than 6000 Lei. About $60 \%$ of respondents have low salaries, $24 \%$ have average salaries, and $17 \%$ have high salaries.

\section{Results}

Opinion poll shows that $98 \%$ of respondents heard of human trafficking. Additionally, Moldovans have shown an intricate understanding of different aspects of human trafficking. More than half (54\%) of the respondents said that people of any age could be trafficked. Polled citizens also have shown concern about the rates of human trafficking in Moldova. More than $64 \%$ of people said that the problem of human trafficking is aggravating, and more people are trafficked compared to previous years.

Furthermore, over $70 \%$ of people said that they have heard of human trafficking in the past weeks or months. These results show that overall the general population is highly aware and concerned with this problem. The rest of this section presents the 
results of tested hypotheses by comparing different groups of people based on their years of education, social class, wages, and residential area.

\section{Education and knowledge}

I hypothesized that education levels do not have a significant impact on public knowledge of human trafficking. This hypothesis is rejected (see Table 2). The results show that there is a negative correlation between level of education and knowledge about human trafficking. People with less education have a more accurate definition of human trafficking; they have the highest tendency to say that people of any gender and any age can be trafficked; they also are the largest group of people who have heard of human trafficking in the last weeks and months. The only indicator that shows support for the organizational assumption is that people with more education can identify more types of human trafficking (see Table 2).

\section{Social class and knowledge}

I hypothesized social class negatively correlates with knowledge about trafficking. These findings find support for the second hypothesis. People from the lower social class are more informed about different aspects of this problem than people from higher social classes. People from lower classes think that people of any gender and any age are at the risk of being trafficked. Furthermore, they enumerated more types of human trafficking (see Table 3).

\section{Wages and knowledge}

I hypothesized that wages negatively correlate with knowledge about trafficking. These findings do not find support for this hypothesis. Instead, these findings find support for organizational assumption, namely that people with higher wages are more informed about different aspects of this problem. However, people from disfavored economic backgrounds with lower wages are more exposed to anti-trafficking information (see Table 4).

\section{Residential area and knowledge}

I hypothesized that area of residence correlates with knowledge about human trafficking. These findings support this hypothesis. I found that people from the rural areas are more informed about different aspects of human trafficking than urban people. I explain that these sharp differences in knowledge based on area of residence arise from several factors. First, rural people are the most informed about this problem because organizations have been targeting, mainly people from the rural area. As has been mentioned before, the strategy of targeting rural residents has been based on organizational assumption that these people are more susceptible to this phenomenon and less informed about trafficking risks.

\section{Discussion}

While anti-trafficking organizations operate under the assumption that poorly educated rural residents do not have the capability or necessary resources to educate themselves about human trafficking, I found the opposite. Counter-trafficking organizations have reached their target audience: rural residents, people from lower social classes, and less education are more informed about human trafficking. Despite the organizations' 
Table 2 The level of education and knowledge about human trafficking

\begin{tabular}{|c|c|c|c|c|}
\hline \multirow{2}{*}{$\begin{array}{l}\text { Dependent } \\
\text { Variables }\end{array}$} & \multicolumn{4}{|c|}{ Independent Variable: Years of education } \\
\hline & less 9 years & $9-12$ & $13-15$ & $16+$ \\
\hline \multicolumn{5}{|c|}{$\begin{array}{l}\text { People of what gender Can be trafficked? } \\
P<.042\end{array}$} \\
\hline Females & $21 \%$ & $28 \%$ & $43 \%$ & $33 \%$ \\
\hline Males & $2 \%$ & $0 \%$ & $0 \%$ & $0 \%$ \\
\hline Any gender & $77 \% *$ & $72 \%$ & $57 \%$ & $67 \%$ \\
\hline \multicolumn{5}{|c|}{$\begin{array}{l}\text { People of what age Can be trafficked? } \\
P<.88\end{array}$} \\
\hline Young & $20 \%$ & $22 \%$ & $26 \%$ & $22 \%$ \\
\hline Mature & $20 \%$ & $20 \%$ & $26 \%$ & $19 \%$ \\
\hline Any age & $60 \%$ & $57 \%$ & $47 \%$ & $59 \%$ \\
\hline \multicolumn{5}{|c|}{$\begin{array}{l}\text { How often do you hear About this problem? } \\
P<.002\end{array}$} \\
\hline Weekly & $46 \%$ & $48 \%$ & $37 \%$ & $28 \%$ \\
\hline Monthly & $44 \%$ & $32 \%$ & $22 \%$ & $33 \%$ \\
\hline Yearly & $10 \% *$ & $20 \%$ & $41 \%$ & $39 \%$ \\
\hline \multicolumn{5}{|c|}{$\begin{array}{l}\text { How many trafficking types Can you enumerate? } \\
P<.034\end{array}$} \\
\hline 1 type & $10 \%$ & $13 \%$ & $7 \%$ & $15 \%$ \\
\hline 2 types & $38 \%$ & $27 \%$ & $50 \%$ & $23 \%$ \\
\hline 3 types+ & $53 \%$ & $59 \%$ & $44 \%$ & $63 \% *$ \\
\hline
\end{tabular}

assumptions, another study also found that accurate information can empower rural people with knowledge on human rights, health, and employment, among others (Hoq 2012).

There are several explanations of why poorly educated rural inhabitants are more informed than others. First, rural residents from lower social classes are more informed about this problem because anti-trafficking organizations have been targeting them more frequently through awareness campaigns (Arap 2017; Rusu 2013). While awareness-raising has been homogeneously distributed throughout the country, targeting vulnerable groups has been performed by portraying these groups of people as more vulnerable to trafficking (Andrijasevic 2007; Revenco 2020). For example, trafficking victims have often been portrayed as women and people from rural regions (IOM 2013; IOM 2018). Also, human trafficking has been occurring more often in rural communities, which means that these residents are exposed to trafficking to a more significant extent (Botchkovar et al. 2016; Buckley 2009; COE 2012; Ghimpu et al. 2011; Panzaru 2013; Robinson 2011; Rusu 2013).

Organizations' assumptions that human traffickers are more successful in rural areas because people have less access to objective information are also aligned with some scholars' views as well (Van Impe 2000). In Albania as in all countries of origin of victims, organizations "run prevention programs including outreach to vulnerable populations such as street children and women in rural areas" (Botchkovar et al. 2016, p. 12) because these people are considered unaware about trafficking risks. Several researchers surveyed the Albanian and Moldovan public and asked, "Who do you perceive to be at 
Table 3 Social class and knowledge about human trafficking

\begin{tabular}{|c|c|c|c|}
\hline \multirow{2}{*}{$\begin{array}{l}\text { Dependent } \\
\text { Variables }\end{array}$} & \multicolumn{3}{|c|}{ Independent Variable: Social class } \\
\hline & Lower class & Middle class & Higher class \\
\hline \multicolumn{4}{|c|}{$\begin{array}{l}\text { People of what gender Can be trafficked? } \\
P<.012\end{array}$} \\
\hline Females & $8 \%$ & $27 \%$ & $40 \%$ \\
\hline Males & $0 \%$ & $0 \%$ & $0 \%$ \\
\hline Any gender & $92 \% *$ & $73 \%$ & $60 \%$ \\
\hline \multicolumn{4}{|c|}{$\begin{array}{l}\text { People of what age Can be trafficked? } \\
P<.000\end{array}$} \\
\hline Young & $0 \%$ & $15 \%$ & $40 \%$ \\
\hline Mature & $15 \%$ & $25 \%$ & $20 \%$ \\
\hline Any age & $85 \% *$ & $61 \%$ & $40 \%$ \\
\hline \multicolumn{4}{|c|}{$\begin{array}{l}\text { How often do you hear About this problem? } \\
P<.169\end{array}$} \\
\hline Weekly & $66 \%$ & $46 \%$ & $66 \%$ \\
\hline Monthly & $26 \%$ & $37 \%$ & $34 \%$ \\
\hline Yearly & $8 \%$ & $17 \%$ & $0 \%$ \\
\hline \multicolumn{4}{|c|}{$\begin{array}{l}\text { How many trafficking types Can you enumerate? } \\
P<.382\end{array}$} \\
\hline 1 type & $0 \%$ & $2 \%$ & $0 \%$ \\
\hline 2 types & $28 \%$ & $25 \%$ & $33 \%$ \\
\hline 3 types+ & $72 \%$ & $67 \%$ & $53 \%$ \\
\hline
\end{tabular}

Note: Sample size $=300$. Cell entries are results of descriptive statistics (crosstabulations) ${ }^{*} p<.05 ;{ }^{* *} p<.01 ;{ }^{* * *} p<.001$

Table 4 Wages and knowledge about human trafficking

\begin{tabular}{|c|c|c|c|}
\hline \multirow{2}{*}{$\begin{array}{l}\text { Dependent } \\
\text { Variables }\end{array}$} & \multicolumn{3}{|c|}{ Independent Variable: Wages } \\
\hline & Low wages & Average wages & High wages \\
\hline \multicolumn{4}{|c|}{$\begin{array}{l}\text { People of what gender Can be trafficked? } \\
P<.000\end{array}$} \\
\hline Females & $34 \%$ & $40 \%$ & $23 \%$ \\
\hline Males & $0 \%$ & $0 \%$ & $0 \%$ \\
\hline Any gender & $66 \%$ & $60 \%$ & $77 \% *$ \\
\hline \multicolumn{4}{|c|}{$\begin{array}{l}\text { People of what age Can be trafficked? } \\
P<.110\end{array}$} \\
\hline Young & $27 \%$ & $17 \%$ & $16 \%$ \\
\hline Mature & $22 \%$ & $30 \%$ & $13 \%$ \\
\hline Any age & $51 \%$ & $53 \%$ & $68 \%$ \\
\hline \multicolumn{4}{|c|}{$\begin{array}{l}\text { How often do you hear About this problem? } \\
P<.104\end{array}$} \\
\hline Weekly & $46 \%$ & $36 \%$ & $41 \%$ \\
\hline Monthly & $32 \%$ & $36 \%$ & $14 \%$ \\
\hline Yearly & $22 \%$ & $27 \%$ & $45 \%$ \\
\hline \multicolumn{4}{|c|}{$\begin{array}{l}\text { How many trafficking types Can you enumerate? } \\
P<.131\end{array}$} \\
\hline 1 type & $10 \%$ & $15 \%$ & $3 \%$ \\
\hline 2 types & $40 \%$ & $31 \%$ & $24 \%$ \\
\hline 3 types+ & $50 \%$ & $54 \%$ & $73 \%$ \\
\hline
\end{tabular}

Note: Sample size $=300$. Cell entries are results of descriptive statistics (crosstabulations) ${ }^{*} p<.05 ;{ }^{* *} p<.01 ;{ }^{* * *} p<.001$ 
greatest risk of being trafficked?" and found the following. In Albania, the public thinks that teenage girls, ethnic minorities, and rural residents to be most at risk of human trafficking. In Moldova, the public thinks individuals from vulnerable families, teenage girls, and rural residents to be most at risk to trafficking (Botchkovar et al. 2016). These findings suggest that organizations' assumptions have been transmitted to the public as well. Mainly, the public has been informed that people with these characteristics are more likely to be trafficked, and that information can prevent them from being trafficked (Andrijasevic 2007; Arap 2017; Robinson 2011).

However, I found this not to be true in Moldova. In fact, throughout my interviews, many rural respondents have said that they know someone who has been exploited abroad or unpaid for their work, which prompts them to share this news and inform themselves about these risks. Thus, I explain that people in those areas are more incentivized to learn about this problem because it happens in their proximity. With this said, people rarely see labor exploitation risks abroad as trafficking-related risks.

Another nuance is that information and news spread differently depending on the locality (Uzezi 2015). Localities in Moldova range from small rural villages, small towns, to suburban areas, including the Capital city with only half a million people. Due to a small population and heavy reliance on mass media, the Moldovan public has been exposed to the same frequency of anti-trafficking campaigns (Revenco 2020; Rusu 2013). I observed that the same campaigns have been influencing public perception in distinctive ways, specifically billboards and educational programs in schools. While urban residents have been exposed to an abundance of information due to broader access to resources and information, massive exposure to anti-trafficking campaigns was something new to rural residents in the early 2000s. In the beginning, people in rural areas showed great interest in finding out more about human trafficking, with time; however, the rural public became uninterested in anti-trafficking campaigns as those became a regular occurrence.

Furthermore, information and news travel faster in small places by word-of-mouth from person to person (Rusu 2013). This practice does not only facilitate a more natural flow of trafficking-related information but adds a twist. The twist occurs when information has been altered when shared from person to person. I have observed this in more than $30 \%$ of people from rural areas. For example, one villager told me that he has heard on the news that several trafficked people were identified in Italy, in the same region of Italy, where he has a cousin. He expressed his deep concern and called his cousin to warn him that there are trafficking risks. This villager has shared this news by adding the story of his cousin.

Personal stories add credibility to the mass media news and bring the problem closer to people in that community (Bradner and Mark 2002). Social psychologists have demonstrated through repeated experiments that information persuades people when it is distributed and shared by people similar to the recipients (Holmes and Singh 2012), which might explain why people are more likely to inform themselves about risks abroad when they know that their friends or relatives inform themselves about these risks. Furthermore, it is not so much about the information circulation as it is about the way people perceive this problem. When a social problem occurs in someone's community, one is more likely to think that he/she is at a higher risk of being exposed to this problem as well. 
Third, data revealed that rural people think of themselves as being at higher risk of trafficking compared to other people. More than $70 \%$ of rural people and only $35 \%$ of urban residents said that they could be trafficked when asked, "If you can be trafficked if you travel abroad uninformed?". On the one hand, counter-trafficking organizations targeted rural people and convinced them that they were prone to being trafficked. On the other hand, many people in rural areas experienced instances of human trafficking in their communities and were more likely to think that this might happen to them too. Hence, these two key elements have played an essential role in leading rural people to believe that they are prone to trafficking. The assumption that the internalization of victimhood leads people to take additional care when seeking employment abroad has not been proved (Andrijasevic 2007). Many studies have shown that an increase in knowledge does not translate in the prescribed behavioral change (Hyman and Sheatsley 1947; Nieuwenhuys and Pécoud 2007; Pécoud 2010), which can explain why some categories of people are more informed about human trafficking yet fail to take proper care when traveling abroad.

\section{Conclusion}

For almost two decades, anti-trafficking organizations, including the UN and EU, have been operating under the assumption that rural populations lack awareness about human trafficking. These organizations have been claiming that if they educated uninformed people to this crime, people would be less susceptible and better informed about it. In this paper, using a mixed-method approach, I tested several hypotheses about whether anti-trafficking organizations have correct assumptions about the public knowledge of human trafficking. First, I analyzed the policy reports published on people's vulnerability to human trafficking, provided by anti-trafficking organizations between 2000 and 2014. Then, I conducted a public survey to measure the general knowledge about this problem. Finally, I compared the public knowledge about this crime with organizational perception about public knowledge. I found that countertrafficking organizations have reached their target audience.

Organizations assume that human trafficking flourishes more in rural areas because people have less access to objective information (Van Impe 2000). They have repeatedly been claiming that poorer and rural people are vulnerable to trafficking and exploitation because of "lack of access to information, knowledge, contacts, and networks" (UN/EU 2011, p. 97). Thus, anti-trafficking organizations have been using information campaigns as an indispensable tool in fighting trafficking because they believed that "they contribute to raising awareness among potential victims regarding the risks of being caught in criminal networks and thus reduce their vulnerability" (Nieuwenhuys and Pécoud 2007, p. 1678). However, my findings show that counter-trafficking organizations do not know what the public knows about this problem.

Despite organizational assumption, I found empirical evidences that rural people are, in fact, more knowledgeable about human trafficking. Rural people are more incentivized to learn about human trafficking because anti-trafficking organizations mainly have targeted them. Rural residents are more likely to know families who have lost members to the traffickers. Rural people tend to think that they are more likely to be trafficked if they would have traveled abroad uninformed. 
While organizational assumptions might have been accurate at the beginning of the 2000s - when human trafficking has emerged as a social problem - this is no longer enough to explain the high rates of trafficking. I argue that information campaigns of anti-trafficking organizations need a complete overhaul and redesign. The depicted range of human trafficking should be expanded to include all possible forms of human trafficking, and not just sex trafficking. By clearly identifying the causal problems of human trafficking and tracking public perception through public surveys, anti-trafficking organizations can better support victims. Releasing concrete guidelines on information around human trafficking and analyzing campaign effectiveness through focus groups would help anticipate and mitigate potential misunderstandings. Close collaboration with local authorities and communities and tailoring campaigns to said local communities (rather than reusing what has been designed by officials in Brussels and Geneva) would dramatically improve public information quality and; aid consistent monitoring of how public perception shifts over time.

\section{Supplementary information}

Supplementary information accompanies this paper at https://doi.org/10.1186/s40878-020-00201-5.

Additional file 1. Residential area and knowledgeable about human trafficking.

\section{Acknowledgements}

Not applicable.

Author's contributions

The author read and approved the final manuscript.

Funding

Not applicable.

\section{Availability of data and materials}

The datasets generated and analyzed during the current study are not publicly available due to the fact that data contains audio and video recordings of the surveyed subjects but are available from the corresponding author on reasonable request.

\section{Competing interests}

The author declares no competing interests.

Received: 14 November 2019 Accepted: 11 August 2020

Published online: 29 October 2020

\section{References}

Andrijasevic, R. (2007). Beautiful dead bodies: gender, migration and representation in anti-trafficking campaigns. Feminist Review 86(1), 24-44.

Arap, I. (2017, April 14). IOM Moldova mission: data limitations and challenges. (L. Bogdan, Interviewer).

Botchkovar, E., Bouche, V., Farrell, A., Whittmer, A. D. (2016). Gauging Public Opinion on Human Trafficking in Moldova and Albania. Employing Survey Experimentation to Inform Effective Prevention and Awareness Programs (Research and Innovation Grants Working Papers Series). Institute of International Education Publication. Retrieved from https://www.iie. org/Research-and-Insights/Publications/DFG-TCU-Publication.

Bradner, E., \& Mark, G. (2002). Why distance matters: Effects on cooperation, persuasion and deception. In Proceedings of the 2002 ACM conference on Computer supported cooperative work (CSCW '02) (pp. 226-235). New York: Association for Computing Machinery. https://doi.org/10.1145/587078.587110.

Buckley, M. (2009). Public opinion in Russia on the politics of human trafficking. Europe-Asia Studies, 61(2), 213-248.

Clark, J. B., \& McArthur, D. (2014). The political and economic transition from communism and the global sex trafficking crisis: A case study of Moldova. Journal of Intercultural Studies, 35(2), 128-144.

COE. (2012). Report concerning the implementation of the Council of Europe Convention on action against trafficking in human beings by the Republic of Moldova. Strasbourg: Council of Europe.

Ghimpu, V., Zaharia, V., \& Porubin, a. N. (2011). Action against human trafficking and domestic violence in Moldova. Chisinau: UNFPA.

GRETA. (2012). Report concerning the implementation of the Council of Europe Convention on action against trafficking in human beings by the Republic of Moldova. Evaluation report. Strasbourg: Council of Europe.

GRETA. (2016). Report concerning the implementation of the Council of Europe Convention on action against trafficking in human beings by the Republic of Moldova (2nd edition). Brussels: Council of Europe. 
Holmes, J. D., \& Singh, S. K. (2012). Student handbook to psychology: Social psychology. New York: Facts on File.

Hoq, K. M. (2012). Role of information for rural development in Bangladesh: A sector-wise review. Information Development, $28(1), 13-21$.

Hyman, H. H., \& Sheatsley, a. P. (1947). Some reasons why information campaigns fail. Public Opinion Quarterly, 11(3), 412-423.

IOM. (2013). Raising awareness of the dangers of human trafficking and irregular migration. Grand-Saconnex: IOM UN

Migration. Retrieved from https://www.iom.int/migrant-stories/raising-awareness-dangers-human-trafficking-and-irregularmigration.

IOM. (2018). Victims of trafficking: Statistical Profile 2018. IOM Moldova. Grand-Saconnex: IOM UN Migration. Retrieved from http://iom.md/sites/default/files/publications/Prevention\%20and\%20protection/pdf/NoT\%20Profile\%202018_MD_En.pdf.

IOM. (2019). Preventing Trafficking and Protecting Victims in Moldova. Grand-Saconnex: IOM UN Migration. Retrieved from https:/ /www.iom.int/preventing-trafficking-and-protectingvictims-moldova.

Kartusch, A. (2001). Reference guide for anti-trafficking legislative review. OSCE ODIHR.

LaStrada (2017). European coalition against trafficking in human beings. Retrieved from http://lastradainternational.org/lsoffices/moldova.

Mahmoud, T. O., \& Trebesch, a. C. (2010). The economics of human trafficking and labour migration: Micro-evidence from Eastern Europe. Journal of Comparative Economics, 38(2), 173-188.

Motriuc, N. (2012). Moldovan migrants find answers through screening of 'abandoned people' theatre play. Chisinau: IOM.

Nanu, C. 2010. Preventing trafficking in human beings: the case of Moldova. In G. Wylie, \& P. McRedmond (Eds.), Human Trafficking in Europe (pp. 142-163). London: Palgrave Macmillan.

Nieuwenhuys, C., \& Pécoud, A. (2007). Human trafficking, information campaigns, and strategies of migration control. American Behavioral Scientist, 50(12), 1674-1695.

OSCE. (2018). Combating human trafficking. Vienna: OSCE. Retrieved from https:/www.osce.org/combating-human-trafficking.

OSCE-Moldova. (2016). OSCE mission to Moldova supports theatre play to raise awareness of trafficking in human beings. Chisinau: OSCE.

Panzaru, C. (2013). Migration and human trafficking. SPECTO, 2000(2010), 449-453.

Pécoud, A. (2010). Informing migrants to manage migration? An analysis of IOM's information campaigns. In M. Geiger, \& A. Pécoud (Eds.), The politics of international migration management (pp. 184-201). London: Palgrave Macmillan.

Radeva, M. (2013, December 18). The ICMPD: Human trafficking, Vienna, Austria, December 201. (L. Bogdan, Interviewer).

Revenco, A. (2020, February). Human trafficking in Moldova. (L. Bogdan, Interviewer).

Robinson, J. (2011). Public perceptions of human trafficking in Moldova. Psychosocial Intervention, 20(3), 269-279.

Rusu, V. (2013, August 23). Raising Awareness Campaigns. (L. Bogdan, Interviewer).

Surtees, R. (2005). Second annual report on victims of trafficking in South-Eastern Europe. Geneva: International Organization for Migration.

UN. (2015). Empowerment of victims of domestic violence and human trafficking in the Transnistrian region of Moldova. Chisinau: United Nations Moldova. Retrieved from http://md.one.un.org/content/unct/moldova/en/home/our-work/joint-un-projects/ closed-projects/empowerment-of-victims-of-domestic-violence-and-human-traffickin.html.

UN/EU. (2011). Human trafficking. Joint UN Commentary on the EU Directive - A Human Rights-Based Approach. Retrieved from https://www.lo.org/wcmsp5/groups/public/\%2D\%2D-europe/\%2D\%2D-ro-geneva/\%2D\%2D-ilo-brussels/documents/ genericdocument/wcms_170010.pdf

UNFPA. (2011). Action against human trafficking and domestic violence in Moldova. Chisinau: United Nations Population Fund.

UN-Moldova. (2007). United Nations Moldova. Retrieved from http//www2.un.md/tenders/12/ToRs\%20National\%20Prayer\%20Day.pdf.

UNODC. (2008). UN.GIFT human trafficking: An overview. Vienna: United Nations Office on Drugs and Crime. Retrieved from https://www.unodc.org/documents/human-trafficking/2008/HumanTrafficking-AnOverview.pdf.

UNODC. (2014). Global report on trafficking in persons. Vienna: United Nations Office on Drugs and Crime. Retrieved from http://www.unodc.org/res/cld/bibliography/global-report-on-trafficking-in-persons_html/GLOTIP_2014_full_report.pdf.

United Nations Development Programme. (2006). UNDP Moldova: Partnering for Development. A Review of the 2002-2006 Country Cooperation Framework of the United Nations Development Programme. Retrieved from http://www.undp.md.

Uzezi, O. P. (2015). Challenges of information dissemination to rural communities: A case of Niger-Delta communities, Nigeria. Journal of Emerging Trends in Computing and Information Sciences, 6, 350-354.

Van Impe, K. (2000). People for sale: The need for a multidisciplinary approach towards human trafficking. International Migration, 38(3), 113-191.

World Bank. (2018). Moldova: Improving access to justice: From recources to results (Report No. 124516-MD). The World Bank. Retrieved from http://documents1.worldbank.org/curated/en/683491537501435060/pdf/Moldova-JSPEIR-English-VersionSep-13-2018.pdf.

\section{Publisher's Note}

Springer Nature remains neutral with regard to jurisdictional claims in published maps and institutional affiliations. 